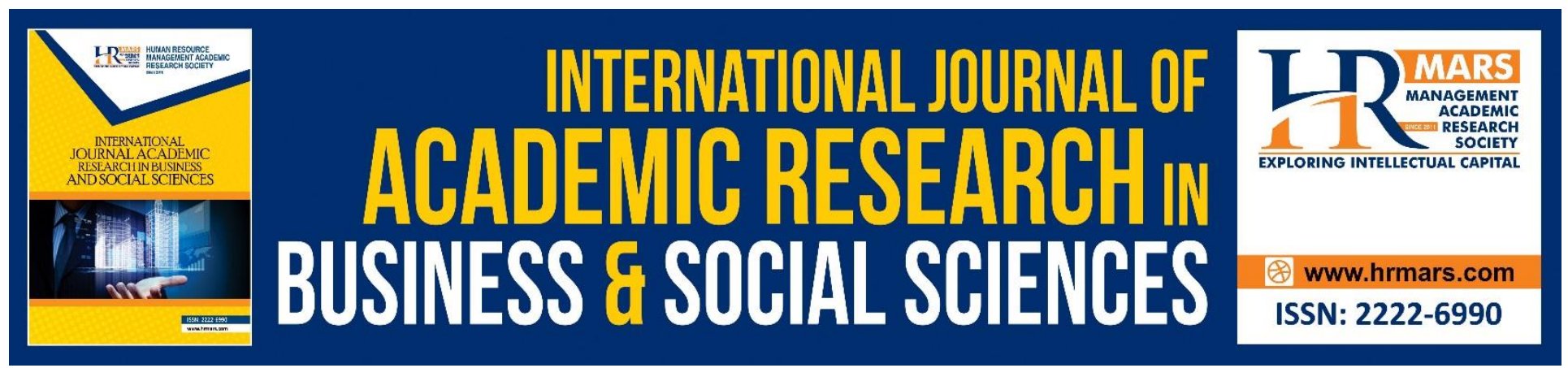

\title{
Effect of Cash Reserves on Performance of Commercial Banks in Kenya: A Comparative Study between National Bank and Equity Bank Kenya Limited
}

Aloys Jared Oganda, Vitalis Abuga Mogwambo, Simeyo Otieno

To Link this Article: http://dx.doi.org/10.6007/IJARBSS/v8-i9/4648 DOI: $10.6007 /$ IJARBSS/v8-i9/4648

Received: 06 August 2018, Revised: 13 Sept 2018, Accepted: 29 Sept 2018

Published Online: 15 October 2018

In-Text Citation: (Oganda, Mogwambo, \& Otieno, 2018)

To Cite this Article: Oganda, A. J., Mogwambo, V. A., \& Otieno, S. (2018). Effect of Cash Reserves on Performance of Commercial Banks in Kenya: A Comparative Study between National Bank and Equity Bank Kenya Limited. International Journal of Academic Research in Business and Social Sciences, 8(9), 685-704.

Copyright: (c) 2018 The Author(s)

Published by Human Resource Management Academic Research Society (www.hrmars.com)

This article is published under the Creative Commons Attribution (CC BY 4.0) license. Anyone may reproduce, distribute, translate and create derivative works of this article (for both commercial and non-commercial purposes), subject to full attribution to the original publication and authors. The full terms of this license may be seen at: $\underline{\text { http://creativecommons.org/licences/by/4.0/legalcode }}$

Vol. 8, No. 9, September 2018, Pg. 685 - 704

Full Terms \& Conditions of access and use can be found at http://hrmars.com/index.php/pages/detail/publication-ethics 


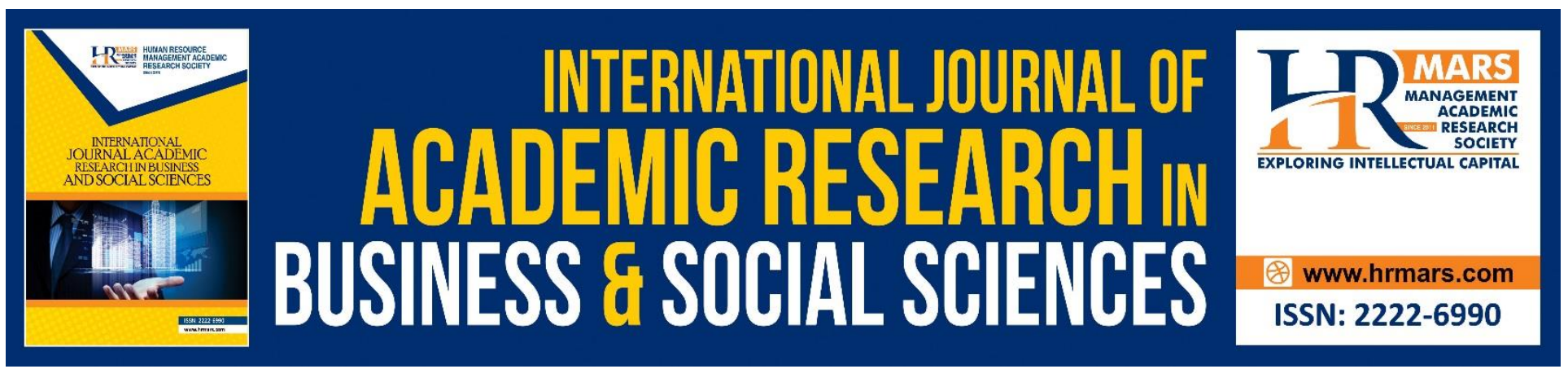

\title{
Effect of Cash Reserves on Performance of Commercial Banks in Kenya: A Comparative Study between National Bank and Equity Bank Kenya Limited
}

\author{
Aloys Jared Oganda \\ MBA Candidate School of Business and Economics, Jaramogi Oginga Odinga University of Science \\ and Technology, Kenya
}

\section{Vitalis Abuga Mogwambo}

Lecturer School of Business and Economics, Jaramogi Oginga Odinga University of Science and Technology, Kenya

\section{Simeyo Otieno}

Lecturer School of Business and Economics, Jaramogi Oginga Odinga University of Science and Technology, Kenya

\begin{abstract}
Banks optimize their liquidity risk by assuming the externalities posed by their choices on the overall risk of the financial system. The banking sector in Kenya has experienced liquidity challenges ranging from funding to market risks. The purpose of this study was to assess the effect of cash reserves on performance of commercial banks in Kenya. The study found that cash reserves had a strong negative correlation with return on equity giving a significant negative relationship with performance of Equity bank. The study recommended that banks should minimize cash reserves and instead invest this money in productive investments, diversify their sources of funding, diversify their investments of these funds.
\end{abstract}

\section{Introduction}

The banking sector plays a critical role in the development process and is expected to drive high levels of savings and financing of Kenya's investment needs. Despite its importance, the sector's growth including other monetary intermediation declined from 10.1 per cent in 2015 to $7.1 \%$ in 2016. Moreover, ROE declined to 24.8 percent in December 2016 from 27 percent in September 2016 (KNBS 
report, 2017). Further, the Kenyan banking sector has experienced a number of challenges including funding and market risks (CBK, 2016). For instance, Imperial Bank Limited and Chase Bank Limited are under receivership while Dubai Bank Kenya Limited was liquidated in 2015 (CBK report, 2016). National Bank is also experiencing liquidity challenges and despite the government ownership of $70.55 \%$ (22.5\%, Treasury and $48.05 \%$, NSSF), it has the highest cost to Income ratio at $64.6 \%$ against the industry average of $47.1 \%$ and the largest NPLs to loans at $42.1 \%$ against the industry average of $10.6 \%$, with one of lowest NPL coverages at $18.1 \%$ against the industry average of $35.4 \%$ (Cytonn Investments report, 2016).

Despite Equity bank having had an improvement in NIM from 10.6\% in 2015 to $11.1 \%$ in 2016, ROE however reduced from $25.5 \%$ in 2015 to $21.5 \%$ in 2016 while ROA declined to $3.7 \%$ in 2016 from $4.5 \%$ in 2016 (Cytonn Investments report, 2017). These banks are exposed to liquidity related risks and inadequate framework to support the banking business. The review of empirical studies showed mixed results as to how and to what extent liquidity risk management affects performance of commercial banks. Therefore this study sought to close the gaps by providing a deeper understanding of the effect of liquidity risk management on the performance of commercial banks in Kenya using a comparative analysis approach.

\section{Objectives of the Study}

The study sought to determine the effect of cash reserves on performance of commercial banks in Kenya.

\section{LITERATURE REVIEW}

This chapter presents the concept of commercial banks, managing cash reserves, sources of liquidity risk, empirical and theoretical literature on liquidity risk management and the performance of commercial banks.

\section{The Concept of Commercial Banks}

A commercial bank is a financial institution, which provides services such as accepting deposits, giving business loans and auto loans, mortgage lending and basic investment products like savings accounts and certificates of deposit. The Banking industry in Kenya is governed by the Companies Act, the Banking Act, the Central Bank of Kenya Act and the various prudential guidelines issued by CBK. Kenya has a total of 42 commercial banks with two banks; Chase bank and Imperial bank in receivership, 1 mortgage finance company, 12 microfinance banks, 8 representative offices of foreign banks, 86 foreign exchange bureaus, 14 money remittance providers and 3 credit reference bureaus (Cytonn, 2017).

\section{Sources of Liquidity Risk for Banks}

Liquidity risk is the possibility that over a specific time period, the bank will become unable to settle obligations with immediacy (Drehmann \& Nikolaou, 2009). The vulnerability of banks to liquidity risk is determined by the funding risk and the market risk. The funding liquidity risk is caused by the maturity mismatch between inflows and outflows and/or the sudden and unexpected liquidity needs due to contingency conditions. The market liquidity risk refers to the inability to sell assets at or near 
INTERNATIONAL JOURNAL OF ACADEMIC RESEARCH IN BUSINESS AND SOCIAL SCIENCES Vol. 8, No. 9, Sept. 2018, E-ISSN: 2222-6990 @ 2018 HRMARS

the fair value, and in the case of a relevant sale in a small market; it can emerge as a price slump (Brunnermeier \& Pedersen, 2009).

On the liability side, there is a large uncertainty on the amount of withdrawals by depositors or renewal of rolled-over inter-bank loans. This is especially so when the bank is under suspicion of insolvency, when there is a temporary shortage of liquidity or when the economy undergoes a macroeconomic shock. On the assets side also, there is some uncertainty on the size of new requests for loans to expect or renewal of existing loans. The bank could refuse to grant these new loans and lead to the contraction of profit due to the foregone interest income. Off-balance sheet operations are a significant source of liquidity risk for banks such as credit lines and other commitments (Rochet, 2008).

\section{Managing Cash Reserves}

These comprise of required reserves and excess reserves. Required reserves are the proportion of deposits Commercial banks are required by law to keep at the Central Bank. When the Central Bank needs to significantly adjust the amount of money circulating in the economy, it can increase or decrease the cash reserves. These reserves are held in the CBK at no interest. They are currently set at 5.25 percent of the total of a bank's domestic and foreign currency deposit liabilities. To facilitate commercial banks' liquidity management, commercial banks are currently required to maintain their cash reserves based on a daily average level from the 15th of the previous month to the 14th of the current month and not to fall below 3 percent on any day (CBK, 2017). Excess reserves are any deposit by a bank with the central bank in excess of the reserve requirement. In a bank's statement of financial position, the cash reserves are referred to as cash and balances with the central bank and they shield the bank against unexpected events such as unusual large withdrawals by depositors or bank runs. A bank always tries to avoid capital injection from the government because it may place it at the government's mercy (Jeanne \& Svensson, 2007). Therefore to avoid this, the bank should hold highly liquid assets as reserves since they can be sold or pledged to meet the funding risks in a short time improve the maturity transformation (Goodhart, 2008).

\section{Bank Performance}

Financial measures are considered the most used parameter of business performance measurement, especially in the current economic climate. These performance indicators are important to the shareholders and depositors who are major beneficiaries of a bank. Profitability is the most important measure of success of a business and it measures the extent to which a business generates a profit from the factors of production; labor, management and capital. Most growing businesses ultimately target increased profits. Bank profitability is the bank's ability to create revenue in excess of cost, in relation to its capital base. A sound and profitable banking sector contributes significantly to financial system stability as it is better placed to withstand negative economic shocks Brissimis, Athanasoglou, \& Delis, (2005). Profitability and liquidity are indicators of corporate health and performance of commercial banks and all profit oriented ventures, (Eljelly, 2004). Profitability analysis focuses on the relationship between revenues and expenses and on the level of profits relative to the size of investment in the business (Mesquita \& Lara, (2003). It is measured by ratios; ROA, ROE and NIM that 
INTERNATIONAL JOURNAL OF ACADEMIC RESEARCH IN BUSINESS AND SOCIAL SCIENCES Vol. 8, No. 9, Sept. 2018, E-ISSN: 2222-6990 @ 2018 HRMARS

summarize large quantities of financial data to make qualitative judgement on performance (Velnampy and Niresh, 2012).

\section{Cash Reserves and Performance of Banks}

Arif and Anees (2012), studied Liquidity risk and performance of banking system in Pakistan focusing on conventional banks. Unstructured interviews were used to gather primary data while secondary data from annual reports was extracted for 22 banks covering a period of 6 years from 2004 to 2009 and used a correlational research design. The study found that increase in cash reserves increases a bank's earnings because adequate cash reserves will also the bank to avoid fire sale risk and decrease the bank's reliance on the repo market thus reducing the cost associated with overnight borrowing. This study recommended that a bank should maintain sufficient cash reserves to mitigate liquidity risk. Despite the recommendation that banks should maintain sufficient cash reserves, the study did not consider the opportunity cost of holding these reserves rather than investing them in earning assets.

Udeh (2015), studied the impact of monetary policy instruments on profitability of commercial banks in Nigeria: a case of zenith bank Plc experience using a descriptive research design. The study utilized time series data collected from published financial statements of Zenith Bank Plc as well as Central Bank of Nigeria Bulletin from 2005 to 2012. Four research questions and four hypotheses were raised for the study. Pearson Product moment correlation technique was used to analyze the data collected while t-test statistic was used in testing the hypotheses. The found a very low positive relationship exists between Profit Before Tax of Zenith Bank plc and the cash reserve rate implying that cash reserve ratio does not have any significant effect on profitability of Zenith Bank Plc and recommended that management of banks should look beyond monetary policies to enhance their profits.

Adebayo, Adeyanju and Olabode (2011) examined liquidity management and profitability of commercial banks Nigeria. The findings of this study indicate that there is significant relationship between liquidity and profitability, meaning that profitability of commercial banks is significantly influenced by liquidity. When banks hold adequate reserves, their profitability would improve. Adequate liquidity helps the bank minimize liquidity risk and financial crises. The bank can absorb any possible unforeseen financial position. However, if liquid assets are held excessively, profitability could diminish because they have no or little interest generating capacity. The opportunity cost of holding low return assets would eventually outweigh the benefit of any increase in the bank's liquidity resiliency as perceived by funding markets (Mashhad, 2013).

Punita \& Somaiya (2006) investigated the impact of monetary policy on the profitability of banks in India between 1995 and 2000. The monetary variables were bank rate, lending rates, cash reserve ratio and statutory ratio, and each regressed on banks profitability independently. Lending rate was found to exact positive and significant influence on banks profitability, which indicates a fall in lending rates will reduce the profitability of the banks. Also bank cash reserve ratio and statutory ratio were found to have significantly affected profitability of banks negatively. 
Mwangi (2014) studied the effect of liquidity risk management on financial performance of Commercial Banks in Kenya. The study involved all the 43 Commercial Banks in Kenya analyzed for a period from 2010-2013. The results of the research showed that liquidity risk management has a significant negative relationship with financial performance of Commercial Banks and concluded that holding more liquid assets as compared to total assets would lead to lower returns to Commercial Banks in Kenya whereas holding more liquid assets as compared to total deposits would lead to lower returns to Commercial Banks in Kenya because the idle liquid assets are not generating income to offset the interest to be paid on the customers deposits.

Tom (2015), studied the effect of liquidity on profitability of commercial banks in Kenya using a descriptive research design approach over a period of 5 years from 2010 to 2014. Secondary data was used and focus was on current ratio, liquidity ratio, deposits and interest rate on profitability and found out that liquidity has a positive effect on profitability of commercial banks. The study concluded that if Liquidity problems are not addressed at the earliest opportunity, depositors demands may prove difficult to meet, bank's profitability and capital would be impaired and in extreme circumstances, it may cause the collapse a bank and recommended that liquidity risk may be mitigated by maintaining sufficient cash reserves. Adequate cash reserves will decrease the bank's reliance on the repo market which consequently will reduce the cost associated with overnight borrowing and insurance cost. The study did not consider the effect of foregone opportunity to invest in the market despite the need to maintain sufficient reserves. Sufficient reserves were not operationalized in the study thus being ambiguous, thus this study will shed light as to the level of cash reserves to hold considering the need to diversify the revenue to the banks and take advantage of current investment opportunities.

\section{Research Gap}

The review of literature show mixed results and conclusions on the effect of liquidity risk management on the performance of a bank. For instance, Otieno et al (2016), found a significant positive relationship between liquidity risk management and financial performance of microfinance banks in Kenya. Macharia (2013) found a positive relationship between liquidity and profitability of banks in Kenya, Lartey et al., (2013) established that there was a very weak positive relationship between the liquidity and the profitability of the listed banks in Ghana while Abera (2012) concluded that the impact of 24 Ethiopian banks' liquidity on their performance remains uncertain and further research is required. Most of the studies relied only on secondary data and thus had the limitation of being obsolete since in our rapidly changing environment, information becomes quickly outdated.

\section{RESEARCH METHODOLOGY}

This study adopted a descriptive survey research design with a comparative analysis approach for it portrays an accurate profile of situations and all the subjects that form the population are included in the sample (Cooper, 1999). The target population for this study comprised of two commercial banks operating in Kenya. To obtain a full view of liquidity risk management and performance of commercial banks in Kenya through a comparative approach, a census of the selected commercial banks was done and for each bank, data was collected for 10 years from 2007 to 2016. Operations 
Directors, Chief Finance Officers, Credit Directors and Treasury Directors of the commercial banks were also interviewed. The data was obtained from published financial statements (audited statements of financial position and income statements) and annual reports obtained from the banks websites and publications from the head offices of the banks. Qualitative data was gathered through an interview schedule. The data analysis for this study was carried out using both descriptive and inferential statistics. SPSS Version 21 software was used to generate descriptive and inferential statistics. Data analysis was guided by correlational matrix.

RESULTS AND DISCUSSION

\section{Performance of commercial banks}

The study sought to establish the performance of commercial banks using three constructs namely ROA, ROE and NIM. The results are presented as in tables below

\begin{tabular}{lcc}
\multicolumn{3}{c}{ ROA (\%) } \\
\hline Statistics & Equity & NBK \\
\hline Mean & 4.828 & 1.619 \\
Median & 4.83 & 1.715 \\
Std. Deviation & 0.64475 & 1.4139 \\
Variance & 0.41571 & 1.9991 \\
Minimum & 3.56 & -0.94 \\
Maximum & 5.64 & 3.37 \\
\hline
\end{tabular}

Source: Research data (2017)

\begin{tabular}{lcc}
\multicolumn{3}{c}{ ROE (\%) } \\
\hline Statistics & Equity & NBK \\
\hline Mean & 25.3 & 10.95 \\
Median & 26.615 & 11.995 \\
Std. Deviation & 6.46 & 10.44 \\
Variance & 41.68 & 109 \\
Minimum & 12.67 & -10.84 \\
Maximum & 33.39 & 22.54 \\
\hline
\end{tabular}

Source: Research data (2017) 
INTERNATIONAL JOURNAL OF ACADEMIC RESEARCH IN BUSINESS AND SOCIAL SCIENCES

Vol. 8, No. 9, Sept. 2018, E-ISSN: 2222-6990 @ 2018 HRMARS

\begin{tabular}{llcc}
\multicolumn{3}{c}{ NIM (\%) } \\
\cline { 2 - 4 } & Statistics & Equity & NBK \\
\hline \multirow{3}{*}{ NIM\% } & Mean & 11.82 & 8.221 \\
& Median & 11.83 & 8.39 \\
& Std. Deviation & 2.181 & 1.138 \\
& Variance & 4.755 & 1.294 \\
& Minimum & 6.53 & 6.44 \\
& Maximum & 14.87 & 10.63 \\
\hline
\end{tabular}

Source: Research data (2017)

Equity bank had a positive financial performance through $2007-2016$. The mean of ROA, ROE and NIM was $4.83 \%, 25.30 \%$ and $11.82 \%$ respectively. Their median was $4.83 \%, 26.62 \%$ and $11.83 \%$ respectively with a minimum of $3.56 \%, 12.67 \%$ and $6.53 \%$ and a maximum of $5.64 \%, 33.39 \%$ and $14.87 \%$. as indicated by tables $4.1,4.2$ and table 4.3 . This suggests that the utilization of assets to generate returns for the bank is low compared to the returns generated by shareholders equity and the positive NIM indicates that there is adequate usage of liabilities to generate wealth in the form of interest income to the bank. There is low variation as indicated by standard deviation of $0.64 \%$, $6.46 \%$ and $2.18 \%$ for ROA, ROE and NIM.

The performance of NBK was negative for one year and then improved thereafter. The mean of ROA, ROE and NIM was $1.62 \%, 10.95 \%$ and $8.22 \%$. This implies that the ability of NBK to generate wealth in relation to its asset base is low as compared to the returns generated using shareholders' funds. The positive NIM indicates that the bank is generating more interest income hence it is paying less interest expense to depositors. The median was $1.72 \%, 11.995 \%$ and $8.39 \%$ for ROA, ROE and NIM respectively with a minimum of $-0.94 \%,-10.84 \%$ and $6.44 \%$ while the maximum was $3.37 \%, 22.54 \%$ and $10.63 \%$ respectively as indicated by tables above.

\section{Cash Reserves and Bank Liquidity}

The study sought to determine the descriptive statistics for cash reserves as a variable for liquidity risk management. The results obtained are as in table below

Cash Reserves and Bank Liquidity

\begin{tabular}{clcc}
\hline & Statistics & Equity & NBK \\
\hline & Mean & 12.672 & 8.173 \\
Cash & Median & 11.165 & 6.725 \\
Reserves & Std. Deviation & 7.70331 & 4.83588 \\
(billions & Variance & 59.341 & 23.3857 \\
& Minimum & 5.15 & 3.37 \\
& Maximum & 30.71 & 16.97 \\
\hline
\end{tabular}

Source: Research data (2017) 
The mean of cash reserves for Equity bank was 12.672 billion, with a minimum and maximum of 5.15 billion and 30.71 billion. There is a high variation in cash reserves maintained by the bank as reflected by a standard deviation of 7.70 billion which is $60.77 \%$ (coefficient of variation) of the mean as indicated in table 4.4. The cash reserves held are in excess of the required reserves. These excess reserves are necessary to shield the bank against liquidity problems by providing a liquidity buffer and hence funds to depositors when needed so as to improve its reputation and win their trust. On the other hand, NBK has a mean of cash reserves of 8.173 billion and a minimum cash reserve level of 3.37 billion and a maximum of 16.97 billion. The variation of cash reserves is high as shown by the standard deviation of 4.84 billion as shown in table 4.4 which translates to $59.22 \%$ which is slightly lower than the percentage variation in Equity bank. Generally, it is observed that Equity bank maintained higher levels of cash reserves as compared to NBK.

\section{Correlation Matrix}

Equity Bank.

Correlation Matrix of Dependent and Independent variables

\begin{tabular}{lcccc}
\hline & ROA & ROE & NIM & $\begin{array}{c}\text { Cash } \\
\text { Reserves } \\
\text { (billions) }\end{array}$ \\
\hline ROA & 1.000 & & & \\
ROE & 0.361 & 1.000 & & \\
NIM & $0.797^{* *}$ & 0.527 & 1.000 & \\
Cash & & & & \\
$\begin{array}{l}\text { Reserves } \\
\text { (billions) }\end{array}$ & -0.03 & $0.672^{*}$ & 0.267 & 1.000 \\
\hline
\end{tabular}

Source: Research Data (2017)

Table 4.27 presents correlations between dependent and independent variables. It is seen that Cash reserves have a negative and insignificant relationship with ROA as shown by the correlation coefficient of -0.03 which implies that banks which maintain high cash reserves as a liquidity risk management variable risk a deterioration in return to the assets since the cash reserves do not generate any return to the bank and thus holding more of them deprives the bank an opportunity to invest the money elsewhere resulting to lower returns to Commercial Banks in Kenya because the idle liquid assets are not generating income to offset the interest to be paid on the customers deposits (Mwangi, 2014). The correlation coefficient is insignificant because normally the cash reserves held form a small proportion to the total assets of a bank. There is a fairly strong and significant positive correlation with ROE of 0.672 . This suggests that concerns that maintain high levels of cash reserves as a liquidity risk management practice result in a significant improvement in return to shareholders wealth and equity. There is however a weak positive and not significant coefficient between cash reserves and NIM ( $r=0.267)$. This implies that as cash reserves increase, the NIM increases but at a slower rate because an increase in these reserves deny the banks the opportunity to invest this money on one hand but on the other hand, the reserves shield the bank during times of huge cash withdrawals as they can go for them instead of selling the earning assets at a fire sale price to avail 
INTERNATIONAL JOURNAL OF ACADEMIC RESEARCH IN BUSINESS AND SOCIAL SCIENCES Vol. 8, No. 9, Sept. 2018, E-ISSN: 2222-6990 @ 2018 HRMARS

the cash to depositors money during withdrawals and therefore, holding adequate cash reserves could assist to even out profits during bad economic times and this could maintain confidence of shareholders and in some instances the reserves could be run down for use in redemption of shares to avoid dilution in ownership, hence the positive significant correlation with ROE of the bank.

National Bank of Kenya

Correlation Matrix of Dependent and Independent variables

\begin{tabular}{lcccc} 
& ROA & ROE & NIM & $\begin{array}{c}\text { Cash } \\
\text { Reserv } \\
\text { es }\end{array}$ \\
\hline ROA & 1.000 & & \\
ROE & $0.975^{* *}$ & 1.000 & & \\
NIM & $0.740^{*}$ & $0.677^{*}$ & 1.000 & \\
Cash & & & & \\
Reserves & $-0.767^{* *}$ & $-0.756^{*}$ & $-0.777^{* *}$ & 1.000 \\
(billions) & & & & \\
\hline
\end{tabular}

**. Correlation is significant at the 0.01 level (2-tailed).

*. Correlation is significant at the 0.05 level (2-tailed).

Source: Research data (2017)

Table 4.28 presents correlations between dependent and independent variables. It is seen that Cash reserves have a negative, strong and significant correlation coefficient with ROA, ROE and NIM as indicated by correlation coefficients of $-0.767,-0.756$, and -0.777 respectively. This concurs with Punita \& Somaiya (2006), who found that cash reserves significantly affected profitability of banks negatively. This because cash reserves do not generate any return to the bank and thus holding more of them deprives the bank an opportunity to invest the money elsewhere resulting to lower returns to Commercial Banks in Kenya because the idle liquid assets are not generating income to offset the interest to be paid on the customers deposits (Mwangi, 2014).

This result differ with equity bank which had a weak negative and insignificant correlation coefficient of -0.03 between cash reserves and ROA, a fairly strong positive and significant correlation of 0.672 between cash reserves and ROE and a weak positive and insignificant correlation coefficient of 0.267 between cash reserves and NIM.

From the interview, respondents described their views on cash reserves, The Director Operations gave an opinion as regards cash reserves and said that "the cash reserve have been fluctuating with both increases and decreases and this depends on the level of cash available and cash needs of the bank but generally, the trend in cash reserves for the past 10 years has been high". This is an indication that the bank had adequate cash levels.

The respondent pointed out that "holding more reserves improved liquidity risk management since the excess reserves held shielded the bank from unforeseen shocks like massive cash withdrawals or 
INTERNATIONAL JOURNAL OF ACADEMIC RESEARCH IN BUSINESS AND SOCIAL SCIENCES Vol. 8, No. 9, Sept. 2018, E-ISSN: 2222-6990 @ 2018 HRMARS

in times of immense funding pressure as they can withdraw the excess reserves and meet their commitments and thus avoid overnight borrowing which is highly expensive". Therefore, the cash reserves improved bank performance as they acted as a buffer and came handy when the bank needed funding in a short time.

\section{Summary of Findings}

Pearson correlation matrix was obtained to determine the association between cash reserves and performance; ROA, ROE and NIM. For Equity bank, Cash reserves were found to have a negative and insignificant relationship with ROA $r=-0.03$, for ROE a fairly strong and significant positive correlation with ROE at $r=0.672$ and a weak positive correlation with NIM as shown by correlation coefficient of 0.267 . For $N B K$, the cash reserves had a negative, strong and significant correlation coefficient with ROA, ROE and NIM as indicated by correlation coefficients of $-0.767(p<0.01),-0.756(p<0.05)$, and $0.777(p=<0.01)$ respectively. Therefore, the study concluded that an increase in cash reserves is detrimental to profitability as these huge reserves are non-income generating assets.

The study recommended that banks should minimize cash reserves and instead invest this money in income generating investments that boosts financial performance. Instead of banks holding their reserves in form of cash, they should hold them in form of near money assets which have a ready market but have also stability in pricing and also adopt an appropriate cash management model that minimizes the possibility of running out of cash. This can be achieved by proper forecasting of cash needs based on past patterns on minimum and maximum cash levels by the bank.

\section{REFERENCES}

Abera, A. (2012). Factors affecting profitability: An empirical study on Ethiopian banking industry, Unpublished Masters' Thesis, Addis Ababa University, Ethiopia.

Adebayo, M., Adeyanju, D., \& Olabode, S. (2011). Liquidity Management and Commercial Banks' Profitability in Nigeria. Research Journal of Finance and Accounting, 2(7/8).

Adebola, S., Yusoff, S. \& Dahalan, D. (2011). An Ardl Approach to the Determinants of Nonperforming Loans. Kuwait Chapter of Arabian Journal of Business and Management Review, Vol. 1, No.2.

Akhtar, S. (2007). Pakistan: changing risk management paradigm - perspective of the regulator. ACCA Conference - CFOs: The Opportunities and Challenges Ahead, Karachi.

Agung, J., Kusmiarso, B. Pramono, .G., Hutapea, A. Prasmuko, \& Prastowo J. （2001), Credit Crunch in Indonesia in the Aftermath of the Crisis: Facts, Causes and Policy Implications, Directorate of Economic Research and Monetary Policy, Bank Indonesia.

Aladwan, M. S. (2015). The Impact of Bank Size on Profitability; An Empirical Study On Listed Jordanian Commercial Banks. European Scientific Journal December 2015 edition vol.11, No.34 ISSN: 1857 - 7881 (Print) e - ISSN 1857- 7431 
INTERNATIONAL JOURNAL OF ACADEMIC RESEARCH IN BUSINESS AND SOCIAL SCIENCES

Vol. 8, No. 9, Sept. 2018, E-ISSN: 2222-6990 @ 2018 HRMARS

Almeida, Heitor, \& Murillo C. (2002) Financial constraints and investment-cash f low sensitivities: New research directions, Working paper, New York University and University of Illinois.

Alper D. \& Anbar . (2011). Bank Specific and Macroeconomic Determinants of Commercial Bank Profitability: Empirical Evidence from Turkey, Business and Economics Research Journal, 2 (2), p. $139-152$.

Al-Tamimi, A. (2008). Implementing Basel II: An Investigation of the UAE Banks' Basel II Preparations, Journal of Financial Regulation and Compliance 16(2), 173-187.

Angbazo, L. (1997). Commercial Bank Net Interest Margins, Default Risk, Interest-Rate Risk, and OffBalance Sheet Banking. Journal of Banking and Finance, 21, 55-87.

Arif A. \& Anees A. (2012). Liquidity Risk and Performance in the Banking System. Journal of Financial Regulation and Compliance, 20(2), 182-195.

Athanasoglou, P., Brissimis, N. \& Delis M. (2008). Bank-Specific, Industry-Specific and Macroeconomic Determinants of Bank Profitability. Journal of International Financial Markets, Institutions and Money, 18(2):121-136.

Barth, J., Nolle, D., Phumiwasana, T., \& Yago G. (2003). A Cross-Country Analysis of the Bank Supervisory Framework and Bank Performance. Financial Markets, Institutions \& Instruments, 12: 67-120.

Basel Committee on Banking Supervision (2008), Principles for sound Liquidity Risk Management and Supervision, Bank of International Settlements.

Bexley. B. \& Nenninger S.(2012), Financial Institutions and the Economy. Journal of Accounting and Finance, 12(1) 2012.

Bologna, P. (2011), Is there a role for funding in explaining recent US bank failures, IMF working paper number wp/11/180

Bonfim, D., \& Kim, M. (2012). Liquidity risk in banking: is there herding? Available at papers.ssrn.com/sol3/papers.cfm?abstract_id=2163547[Accessed 03/12/2018]

Boudriga, A, Boulila, N, \& Jellouli, S., (2009). Does Bank Supervision Impact Nonperforming Loans: Cross-Country Determinants Using Aggregate Data. Unpublished Manuscript.

Bourke, P. 1989. Concentration and Other Determinants of Bank Profitability in Europe, North America, and Australia. Journal of Banking and Finance, 13(1): 65-79. 
INTERNATIONAL JOURNAL OF ACADEMIC RESEARCH IN BUSINESS AND SOCIAL SCIENCES

Vol. 8, No. 9, Sept. 2018, E-ISSN: 2222-6990 (C) 2018 HRMARS

Brissimis, S., Athanasoglou, P., \& Delis, M. (2005). Bank-specific, Industry-specific and Macroeconomic determinants of bank profitability. Working Paper-Bank of Greece, 25.

Bryman, A. (2012). Social research methods (4th ed.). New York: Oxford University Press. Nairobi. Central Bank of Kenya.

Central Bank of Kenya,(2011). Bank supervision annual report 2011. http://www.centralbank.go.ke/downloads/acts_regulations/banking_Act.pdf

Central Bank of Kenya,(2016). Bank supervision annual report 2016. http://www.centralbank.go.ke/downloads/acts_regulations/banking_Act.pdf

Chaplin, G., Emblow, A. \& Michael, I. (2000). Banking system liquidity: Developments and issues. Financial Stability Review, December, 93-112.

Chege, L. M., \& Bichanga, J. (2017). Non-Performing Loans and Financial Performance of Banks: An Empirical Study of Commercial Banks in Kenya International Journal of Management and Commerce Innovations, Vol. 4, Issue 2, pp: (909-91)

Choi, L. (2001). Unit root test for panel data. Journal of international money and finance 20:249-272

Comptroller of the Currency (2001). Liquidity: Comptroller's Handbook, Comptroller of the Currency: Administrator of the National Banks, Washington, DC.

Cooper, D., \& Schindler, P. (2008). Business Research Methods. (10th ed). Singapore: McGraw-Hill.

Cooper, D., \& Schindler, P. (2011). Business Research Methods. (11th ed.). New York: McGrawHill.

Cronbach, L. (2004). My current thoughts on coefficient alpha and successor procedures. Educational and Psychological Measurement 64, 391-418.

Crowe, K. (2009). Liquidity risk management - more important than ever. Harland Financial Solutions, p. 3.

Crowther, D. \& Lancaster, G. (2008). Research Methods: A Concise Introduction to Research in Management and Business Consultancy, Butterworth-Heinemann

Cytonn Investments, (2016) Kenya Banking Sector Report 2016. 
INTERNATIONAL JOURNAL OF ACADEMIC RESEARCH IN BUSINESS AND SOCIAL SCIENCES

Vol. 8, No. 9, Sept. 2018, E-ISSN: 2222-6990 (C) 2018 HRMARS

Deloitte, (2017) Kenya Financial Sector Stability Report 2016.

Devinaga, R. (2010). Theoretical Framework of Profitability as Applied to Commercial Banks in Malaysia. European Journal of Economics, Finance and Administrative Sciences 23, 149 -160.

Diamond, D.W., \& Rajan, R.G. (2001). Liquidity risk, liquidity creation, and financial fragility: a theory of banking. The Journal of Political Economy, 109(2), 287- 327.

Diamond, W., \& Rajan, G. (2005). Liquidity shortages and banking crises. The Journal of Finance, 60(2), $615-47$.

Drost, E. A. (2012). Validity and Reliability in Social Science Research. Education Research and Perspectives, 38(1), 105-123.

Ebba, M. K. (2016). The relationship between non-performing loans and financial Performance of commercial banks in Ethiopia. Unpublished Master's Thesis. University of Nairobi, Kenya.

Eljelly, A. (2004). The cyclical behavior of optimal bank capital. Journal of Banking and Finance, 28(3), 1469-1498.

Epure, M. \& Lafuente, I. (2012). Monitoring Bank Performance in the Presence of Risk, Barcelona GSEWorking Paper Series No.61.

Ezra, M. (2013). Determinants of Commercial Bank Profitability in Sub-Saharan Africa. International Journal of Economics and Finance; Vol. 5, No. 9; 2013 ISSN 1916-971X E-ISSN 1916-9728

Financial Stability Oversight Annual Report (2015), Nairobi: Government Printer

Gatev, E. \& Strahan, P. (2003). Banks' advantage in hedging liquidity risk: theory and evidence from the commercial paper market. working paper, The Wharton Financial Institutions Centre, Chestnut Hill, MA.

Goddard, J., Molyneux, P. \& Wilson, J. (2004).The Profitability Of European Banks: A Cross-Sectional And Dynamic Panel Analysis.The Manchester School Vol 72 No. $3,1463-6786$ 363-381

Goodhart, C. (2008). Liquidity risk management. Financial Stability Review, 11(6).

Greenidge,K.\& Grosvenor,T.(2010), Forecasting Non-performing Loans in Barbados. 
INTERNATIONAL JOURNAL OF ACADEMIC RESEARCH IN BUSINESS AND SOCIAL SCIENCES Vol. 8, No. 9, Sept. 2018, E-ISSN: 2222-6990 (C) 2018 HRMARS

Journal of Business, Finance and Economics in Emerging Economies, 5, 80-107.

Guglielmo, M. (2008). Managing liquidity risk. Bank Accounting \& Finance, 8.

Gujarati, D. (2004). Basic Econometrics $4^{\text {th }}$ Edition, McGraw Hill

Guy K (2011), Non-performing Loans.The Central Bank of Barbados Economic Review Volume XXXVII, Number 1

Hadad, F. (2013). Financial performance of Rural Banks in Ghana: A Case Study on Naara Rural Bank. European Journal of Banking and Finance, Vol.11.

Hassan, A. (2009). "Risk management practices of Islamic banks of Brunei Darussalam". The Journal of Risk Finance, 23-37.

Holmstrom, B. \& Tirole, J. (2000). Liquidity and risk management. Journal of Money Credit and Banking, 32(3), 295-319.

Horváth, R., Seidler, J., \& Weill, L. (2014). Bank Capital and Liquidity Creation: Granger-Causality Evidence. Journal of Financial Services Research, 45(3), 341-361.

Hou, Y \& Dickinson, D. (2007). "The Non-Performing Loans: Some Bank-level Evidences, Research Conference on Safety and Efficiency of the Financial System.

Ibe, S. (2013). The Impact of Liquidity Management on the Profitability of Banks in Nigeria. Journal of Finance and Bank Management 1(1); June 2013 pp. 37-48

lion, T. \& Dragos, P. (2006), "Policies of the Commercial Banks Liquidity Management in the Crisis Context", Bank of Romania Working Paper.

International Monetary Fund, (2017) Country Report No. 17/25, Kenya 2017.

Investopedia, (2017). http://www.investopedia.com/

Iqbal, Z. \& Mirakhor, A. (2011), An Introduction to Islamic Finance: Theory and Practice, 2nd ed., Wiley, Singapore.

Ismal, R. (2010). Strengthening and improving the liquidity management in Islamic banking, Humanomics 26(1): 18-35 
INTERNATIONAL JOURNAL OF ACADEMIC RESEARCH IN BUSINESS AND SOCIAL SCIENCES Vol. 8, No. 9, Sept. 2018, E-ISSN: 2222-6990 (C) 2018 HRMARS

Jeanne, O. \& Svensson, L. (2007). Credible commitment to optimal escape from a liquidity trap: the role of the balance sheet. The American Economic Review, $97 \quad$ (1), 474-7490.

Jenkinson, N. (2008). Strengthening regimes for controlling liquidity risk. Euro Money Conference on Liquidity and Funding Risk Management, Bank of England, $\quad$ London, p. 9.

Kashyap, A, Rajan, D. \& Stein, J. (2002): “Banks as liquidity providers: an explanation for the coexistence of lending and deposit-taking", Journal of Finance, vol 57, no 1, p 33-73.

Kazi, A. M. (2012). Promoting deposit mobilization and financial inclusion.

Khan, M.M. and Bhatti, M.I. (2008). "Development in Islamic banking: a financial risk allocation approach", The Journal of Risk Finance, Vol. 9 No. 1, pp. 40-51.

Kenya National Bureau of Statistics (2017). Economic Survey. Nairobi: Government Printer.

Kenya National Bureau of Statistics (2013). Economic Survey. Nairobi: Government Printer.

Kiragu. .C. M. (2010).The Relationship between Profitability and Capital Adequacy of Commercial Banks in Kenya. Unpublished Master's Thesis. University of Nairobi, Kenya.

Kithinji, A. M. (2010): Credit Risk Management and Profitability of Commercial Banks in Kenya. Unpublished Masters Dissertation. University of Nairobi, Kenya.

Konadu, J.S. (2009). Liquidity and Profitability: Empirical evidence from banks in Ghana. Unpublished Masters' Thesis, Kwame Nkrumah University of Science and Technology, Ghana

KosmidoU, K., Tanna, S., \& Pasiouras, F. (2005). Determinants of Profitability of Domestic UK Commercial Banks: Panel Evidence from the Period 1995-2002. Working Paper.

Kumar, S., \& Yadav, S. (2013). Liquidity management and commercial banks' profitability. International Research Journal of Finance and Economics, 5(8) 226-241.

Lartey, V., Antwi, S., \& Boadi, E. (2013). The relationship between liquidity and Profitability of listed banks in Ghana. International Journal of Business and Social Science, 4(3), 48-56. 
INTERNATIONAL JOURNAL OF ACADEMIC RESEARCH IN BUSINESS AND SOCIAL SCIENCES

Vol. 8, No. 9, Sept. 2018, E-ISSN: 2222-6990 (C) 2018 HRMARS

Liu, S. (2013). Determinants of the profitability of the U.S. banking industry during the Financial crisis. Unpublished Master's Thesis. Clemson University, United States Of America.

$\mathrm{Li}, \mathrm{Y}$. (2007). Determinants of banks profitability and its implication on risk Management practices, Unpublished Doctoral dissertation. The University of Nottingham, United Kingdom.

Lucey, T. (2002). Quantitative Techniques $6^{\text {th }}$ Ed. Bookpower.

Lukorito,S.N, Muturi,W., Nyang'au .S. A. \& Nyamasage .D. (2014). Assessing the effects of Liquidity on profitability of commercial banks in Kenya. Journal of Finance and Accounting Vol.5 143- 152.

Louzis, D.P., Vouldis, A.T., \& Metaxas, V.L. (2010), Macroeconomic and bank-specific determinants of non-performing loans in Greece: a comparative study of mortgage, business and consumer loan portfolios. Bank of Greece, Working Paper, 118.

Maaka, Z. A. (2013). Relationship between liquidity risk and financial performance of commercial banks in Kenya. Unpublished master's Dissertation University of Nairobi, Kenya.

Mahshid S. (2013).The impact of liquidity asset on Iranian banks profitability, International conference on management, behavioral sciences and Economics issues. Malaysia: Penang.

Majid, A. (2003). Development of Liquidity Management Instruments: Challenges and Opportunities: International Conference on Islamic Banking: Risk Management, Regulation and Supervision.

Mehmed, G. (2014). An empirical study on Liquidity risk and its determinants in Bosnia and Herzegovina: The Romanian Economic Journal, XVII no. 52.

Molyneux P, Thornton J. (1992). "Determinants of European Bank Profitability: A Note, "Journal of Banking and Finance, Vol. 16, 1173-1178.

Mpuga, P. (2002). The 1998-99 Banking crises in Uganda: What was the role of the new capital requirement? "Journal of financial regulation and compliance, Vol.10.Iss: 3 pp; 224-242.

Mugenda, O.M. \& Mugenda, A.G. (2003). Research methods: Quantitative and qualitative approaches.2nd. Rev. ed. Nairobi: Act press. 
INTERNATIONAL JOURNAL OF ACADEMIC RESEARCH IN BUSINESS AND SOCIAL SCIENCES

Vol. 8, No. 9, Sept. 2018, E-ISSN: 2222-6990 @ 2018 HRMARS

Munther,N,Warrad,L,\& Omari,R.(2013). The Impact of liquidity on Jordanian banks Profitability through return on assets. Interdisciplinary Journal of Contemporary Research in Business.

Murerwa, C. B. (2015). Determinants of banks' financial performance in developing Economies: evidence from Kenyan commercial banks. Unpublished MBA research project, United States International University - Africa

Mwangi, F. (2014). The effect of liquidity risk management on the financial Performance of Commercial Banks in Kenya. Unpublished MSC in Finance research project, The University of Nairobi, Kenya.

Mwathi, Z.N (2009). The relationship between commercial banks financial performance and ownership structure. Unpublished Masters Thesis. University of Nairobi, Kenya.

Naceur, S.B. and Goaied M. (2001), The determinants of the Tunisian deposit banks; Performance, Applied Financial Economics Vol. 11 Issue 3, pp 317-319

Nafula, N.N. (2003). Bank Portfolios and Bank Earnings in Kenya: An Econometric Analysis. Social Sector Division Kenya Institute for Public Policy Research and Analysis KIPPRA Discussion

Nikolaou, K., (2009). Liquidity risk concepts: definitions and interactions, $E C B$ Working Paper No. 1008.

Odunga, R. M., \& Nyangweso, P. M. (2014). Credit risk, liquidity and operating efficiency for low and high market shares commercial banks in Kenya. Unpublished master's Dissertation Moi University, Kenya.

Okun, D. M. (2012). The Effect Of Level Of Deposits On Financial Performance Of Commercial Banks In Kenya. Unpublished Masters Dissertation, University of Nairobi, Kenya.

Orodho, J.A. (2008). Techniques of writing research proposals \& reports in education and social sciences. Nairobi: Kanezja HP Enterprises.

Otieno, S. Nyagol, M. \& Onditi, A. (2016). Empirical analysis on relationship between liquidity risk management and financial performance of microfinance banks In Kenya: Research journal of finance and accounting vol.7

Ozurumba, B. A. (2016). Impact of Non-Performing Loans on the Performance of Selected Commercial Banks in Nigeria; Research Journal of Finance and 
INTERNATIONAL JOURNAL OF ACADEMIC RESEARCH IN BUSINESS AND SOCIAL SCIENCES Vol. 8, No. 9, Sept. 2018, E-ISSN: 2222-6990 (C) 2018 HRMARS

Accounting www.iiste.org ISSN 2222-1697 (Paper) ISSN 2222-2847 (Online) Vol.7, No.16, 201695.

Pallant, J. (2010). SPSS Survival Manual. A step by step guide to data analysis using SPSS (4th ed.). Melbourne: Open University Press.

Punita, R. and Somaiyi, K. J. (2006) Monetary Policy; Its impact on profitability of banks in India, intermediate business and economics research journal; vol 5, no.3 pp 15-19

Ratnovski, L., and Huang, R. (2009) Why are Canadian Banks more resilient; IMF working paper number WP/09/152

Reinhart, Carmen M., \& Kenneth S. R. (2010). "Growth in a Time of Debt" American Economic Review, 100 (2): 573-78.

Rochet,J. C., (2008). Liquidity regulation and the lender of last resort; Journal of financial stability, 1 (1), $93-110$.

Sohiami, A.N.A. (2013), Liquidity Risk and Performance of Banking System in Malaysia, Mara University of Technology Johor, Malaysia.

Summers, B. J. (1975). Loan Commitments to business in United states banking history. Economic review, Federal Reserve Bank of Richmond, 61, 15- 23. http://www.richmondfed.org/publications/research/economic review/1975/pdf/er610502.pdf.

Tom, M. O. (2015). Effects of Liquidity Risk on Profitability of Commercial Banks in Kenya, Unpublished Masters' Thesis, University of Nairobi.

Udeh, S. N. (2015). Impact of monetary policy instruments on profitability of Commercial banks in Nigeria: Zenith Bank experience. Research Journal of Finance and Accounting, 6(10): 190-205.

Vaidyula, S.R and Kavala, J. (2013) : Enterprise risk management for Banks

Van Greuning, H. and Iqbal, Z. (2008): Risk Analysis for Islamic Banking.Washington: the International Bank for Reconstruction and Development

Velampy, J. \& Niresh, A. (2012). The Bankrelationship between capital structure and profitability. Global Journal of Management and Business Research. Vol. 12 Issue 13 Version 1.0.ISSN; 2249-4588. 
INTERNATIONAL JOURNAL OF ACADEMIC RESEARCH IN BUSINESS AND SOCIAL SCIENCES Vol. 8, No. 9, Sept. 2018, E-ISSN: 2222-6990 @ 2018 HRMARS

Waweru, N.M., \& Kalani, V.M., (2009). Commercial Banking Crises in Kenya: Causes and Remedies. Global Journal of Finance and Banking Issues, 3(3), 67.

Were, M. \& Tiriongo, S. (2012). Central Bank's Response to Economic Crises from a Developing African Economy Perspective: Lessons from Kenya's Experience. 